\title{
Improvement of the innovation management system in the manufacturing industry
}

\author{
Vitaly Makoveev ${ }^{1}$, Liliya Mukhametova ${ }^{2}$ \\ ${ }^{1}$ Vologda state University \\ ${ }^{2}$ Kazan State Power Engineering University, str. Krasnoselskaya, 51, 420066, Kazan, Russia
}

\begin{abstract}
Sustainable long-term development of the energy sector is impossible without a developed manufacturing industry and especially machine-building enterprises. The article identifies the factors that have the greatest impact on the development of innovation in the manufacturing industry. A multi-factor regression model is constructed to determine the degree of influence of various socio-economic factors on the level of innovation development in manufacturing industries. An organizational and economic mechanism aimed at enhancing innovation in the manufacturing industry and increasing the competitiveness of the products of enterprises in this sector is proposed.
\end{abstract}

\section{Introduction}

Sustainable long-term development of the energy sector is impossible without a developed manufacturing industry and especially machine-building enterprises. The manufacturing industry is one of the drivers of innovative development of the economy, since it is in this sector that the production of the most technologically complex and high-tech products with high added value is concentrated. The variety of technological processes focused on manufacturing enterprises, on the one hand, makes this sector the main source of innovative products, goods and services, and on the other hand, it is the main consumer of a wide range of innovative developments.

Currently, the Russian Federation has developed a certain regulatory framework aimed at stimulating innovation in the manufacturing industry. Developed and adopted the laws "On science and state scientific and technical policy" (1996) and "On industrial policy in Russia" (2014), approved the "Strategy for innovative development of the Russian Federation for the period till 2020 " and the state program "Developing industry and increasing its competitiveness", "Economic development and innovative economy". Similar regulations, strategies, programs, and roadmaps have been adopted at the regional level.

Priority directions and main goals of state support for innovation activities are defined in the framework Of the "strategy for innovative development of the Russian Federation until 2020", approved by the Government on 08.12.2011 No. 2227-R. One of the key indicators outlined in this document are:

- increase in the share of industrial enterprises engaged in technological innovations in the total number of industrial enterprises from $10-15 \%$ to $40-50 \%$;
- increasing the share of Russian high-tech exports in the total global volume of high-tech exports from $0.3 \%$ to $2 \%$;

- increasing the share of innovative products in the total volume of industrial production from $5-7 \%$ to 20 $35 \%$.

However, despite the efforts made, the pace of development of innovative activity in the manufacturing industry remains extremely insufficient to achieve the indicators outlined in the Strategy and turn this sector into the engine of innovative development of the country's economy.

First of all, this is confirmed by the extremely low growth rates of the level of innovation activity of manufacturing enterprises. For the period 2005-2013, the level of innovation activity in this sector did not exceed $13 \%$, and the share of innovative products in the total volume of shipped products - 12\% (table 1). for comparison, in European countries, the level of innovation activity of industrial enterprises is significantly higher, for example, in Finland it is $52.5 \%$, in Germany $-71.8 \%$, in France - $40.1 \%$.

Insufficient activity of innovation activity is the main factor of low competitiveness of products produced by the domestic processing complex. As a result, in 2012 Russia occupied only $0.3 \%$ of the world market for machine-building products.

The identification of other factors that have the greatest impact on the level of innovation development in the manufacturing industry was carried out on the basis of factor and correlation-regression analysis of manufacturing activities in the period 2006-2013 for all subjects of the Russian Federation (640 observation points).

The index reflecting the level of development of innovative activity in the manufacturing industry was 
Table 1. Indicators that reflect the level of innovation development in the Russian manufacturing industry.

\begin{tabular}{|l|c|c|c|c|c|c|}
\hline \multicolumn{1}{|c|}{ Indicator } & \multicolumn{3}{c|}{ Year } & \multirow{2}{*}{$\begin{array}{c}2013 \text { to } 2005 \\
\text { ח.п. }\end{array}$} \\
\cline { 2 - 6 } & 2005 & 2010 & 2011 & 2012 & 2013 & 1,0 \\
\hline Level of innovation activity of MI enterprises, \% & 10,9 & 11,3 & 11,6 & 12,0 & 11,9 & $-13,0$ \\
\hline $\begin{array}{l}\text { MI contribution to the total volume of innovative } \\
\text { products, \% }\end{array}$ & 84,8 & 79,7 & 62,1 & 68,7 & 71,8 & \\
\hline $\begin{array}{l}\text { Share of innovative products shipped by MI in the total } \\
\text { volume of goods shipped, works performed, services, \% }\end{array}$ & 7,0 & 6,7 & 6,8 & 9,6 & 11,6 & 4,6 \\
\hline $\begin{array}{l}\text { MI - manufacturing industry. } \\
\text { Source: Federal state statistics service. Mode of access: http://www.gks.ru; }\end{array}$ &
\end{tabular}

Table 2. Ranking of constituent entities of the Russian Federation in terms of development of innovative activity in manufacturing industry.

\begin{tabular}{|c|c|c|c|c|}
\hline \multirow{2}{*}{ Territory } & \multicolumn{2}{|c|}{$2006-2009$ years } & \multicolumn{2}{|c|}{$2010-2013$ years } \\
\hline & Index value & Rank & Index value & Rank \\
\hline Samara region & 0,707 & 1 & 0,692 & 1 \\
\hline Republic of Mordovia & 0,570 & 5 & 0,685 & 2 \\
\hline Moscow & 0,569 & 7 & 0,644 & 3 \\
\hline Lipetsk region & 0,523 & 10 & 0,637 & 4 \\
\hline Chuvash Republic & 0,518 & 13 & 0,622 & 5 \\
\hline Perm region & 0,672 & 2 & 0,613 & 6 \\
\hline Saint-Petersburg & 0,569 & 6 & 0,613 & 7 \\
\hline Nizhniy Novgorod region & 0,578 & 3 & 0,612 & 8 \\
\hline Ulyanovsk region & 0,572 & 4 & 0,598 & 9 \\
\hline Yaroslavl region & 0,503 & 19 & 0,574 & 10 \\
\hline \multicolumn{5}{|c|}{ } \\
\hline Trans-Baikal Krai (Territory) & 0,231 & 67 & 0,162 & 71 \\
\hline Republic Of North Osetia-Alania & 0,212 & 68 & 0,153 & 72 \\
\hline Republic Of Sakha (Yakutia) & 0,098 & 75 & 0,128 & 73 \\
\hline Republic Of Tyva & 0,104 & 72 & 0,121 & 74 \\
\hline Jewish Autonomous region & 0,101 & 78 & 0,106 & 75 \\
\hline Chukotka Autonomous region & 0,092 & 76 & 0,103 & 76 \\
\hline Magadan region & 0,132 & 72 & 0,078 & 77 \\
\hline Republic of Ingushetia & 0,000 & 79 & 0,049 & 78 \\
\hline Chechen Republic & 0,000 & 80 & 0,009 & 79 \\
\hline Republic Of Kalmykia & 0,000 & 78 & 0,009 & 80 \\
\hline
\end{tabular}

chosen as the effective indicator, which was calculated by aggregating the following 4 effective indicators into an integral one:

1. the Share of innovative products shipped by enterprises of the processing complex in the total volume of products shipped (this indicator reflects the volume of innovative products produced by enterprises of the processing complex. The higher the value of this indicator, the more dynamic the diffusion of innovations is).

2. the Share of innovative products shipped by enterprises of the processing complex in the total volume of innovative products in the region (this indicator allows you to determine the contribution of enterprises of the processing complex to the formation of the total volume of innovative products created in the region).

3 . the level of innovation activity of manufacturing enterprises (this indicator allows you to assess the degree of involvement of manufacturing enterprises in innovation).

4. the Volume of innovative products shipped by enterprises of the processing complex per employee (this indicator allows you to measure labor productivity in terms of production of innovative products).

Based on the calculation of the index, it was found that a high level of innovation development in the manufacturing industry was observed in the regions and cities of the Volga (Samara, Nizhny Novgorod and Ulyanovsk regions, the Republic of Mordovia, the Chuvash Republic and Perm Krai), Central (Lipetsk and Yaroslavl regions, Moscow) and North-Western (Saint Petersburg) Federal districts. Among the regions with the lowest level of innovation activity development in the manufacturing industry entered the territory of the far Eastern (Jewish Autonomous oblast, Republic of Sakha (Yakutia), Magadan oblast and Chukotka Autonomous district), Siberian (Tuva Republic and Trans-Baikal Krai (territory)), South (Republic of Kalmykia) and North Caucasian (Chechen Republic and Republic Ingushetia and North Ossetia - Alania) Federal districts (table. 2).

As dependent variables that influence the level of innovation development in the manufacturing industry, 17 socio-economic indicators were studied, for which there was a necessary statistical base and the possibility of its quantitative and qualitative assessment. Based on 
the correlation analysis, it was found that out of 17 selected indicators, 8 indicators had a fairly close relationship with the level of innovation development in the manufacturing industry. They were grouped into three components: financial (f), human resources (HR), and production $(\mathrm{P})$.

The financial component included such indicators as: the share of expenditures on technological innovations of manufacturing enterprises in the total volume of expenditures on technological innovations; the share of investments in fixed assets of manufacturing enterprises in the gross regional product; the ratio of the average salary of employees of manufacturing enterprises to the average salary for the region's economy.

The personnel component includes: the share of personnel engaged in research and development in the total number of economically active population; the number of issued protection documents for inventions and utility models (per 10 thousand population); the share of the population with higher education in the total number of employees in the economy; the number of organizations performing research and development (per 10 thousand population).

The production component includes an indicator that reflects the degree of depreciation of fixed assets of manufacturing industries.

Based on the correlation and regression analysis of the resulting indicator, which was used as an index reflecting the level of innovation development in the manufacturing industry (IDmi), and the selected components, the regression equation is obtained:

$$
\text { IDmi }=0.39+0.12 * \mathrm{~F}+0.04 * \mathrm{HR}-0.05 * \mathrm{P}
$$

The quality of the obtained model is confirmed by significant coefficients of multiple correlation (0.72) and determination (0.52), as well as high values of the Fisher criterion (227.5).

The coefficients of the regression equation indicate that the level of innovation development in the manufacturing industry is most dependent on financial factors, which account for $27 \%$ of the variation. The HR and production components account for $24 \%$ and $11 \%$, respectively.

The obtained mathematical dependence shows that the increase in the level of development of innovation activities in manufacturing can be achieved due to the growth of financial and human factors (with increasing values of the financial and staffing components $1 \%$ an index reflecting the level of development of innovative activity in the manufacturing sector increased by 0.12 and 0.04 , respectively), as well as reducing the negative production factors (reduction of value of components production by $1 \%$ increases the index, reflecting the level of innovation development in the manufacturing industry by 0.05 ).

The results of the regression analysis correlate with the results of surveys of managers of manufacturing

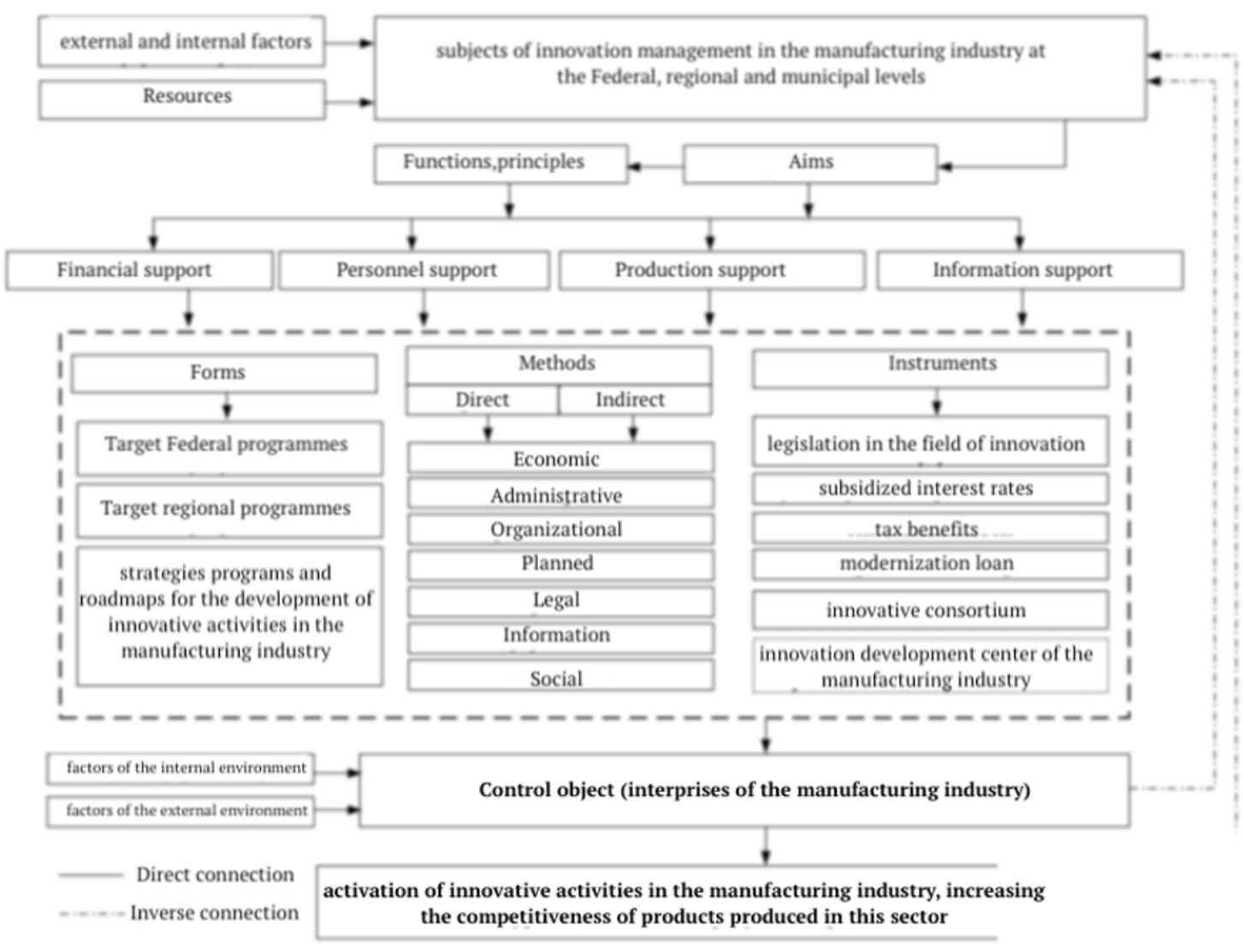

Fig. 1. Conceptual scheme of the mechanism of management of innovative activity in the manufacturing industry. 
enterprises in the Vologda region, which were conducted annually from 2005 to 2013 by employees of ISERT RAS. For example, in 2013 among the main factors hindering the development of innovation in the manufacturing industry, business leaders note: lack of own funds $(66 \%)$, high cost of innovations $(54 \%)$, lack of financial support from the state $(50 \%)$, progressive depreciation of fixed assets (39\%), lack of qualified personnel $(30 \%)$.

Thus, summarizing the obtained results, we can conclude that the increase in the financing of innovation activities, increasing the number of organizations and staff engaged in research and development, increase the wages of workers in the manufacturing sector, as well as inventive activity and education level of the population by reducing the degree of wear of fixed assets of manufacturing industries creates prerequisites for the intensification and development of innovative activities in the manufacturing industry. This confirms the significant role of socio-economic factors in the development of innovative activities in the manufacturing industry and the need to create conditions on the part of state authorities and management to stimulate the financing of research and development, the development of human resources and the modernization of the manufacturing industry.

The existence of various problems in the field of innovation development in the manufacturing industry is largely due to the wide range of participants and the complex nature of interaction between them.

This creates the need of a systemic approach to management, which leads to the development of the mechanism of management of innovative activity in the manufacturing sector, which can be defined as the totality of forms, methods, tools and supporting systems through which public authorities and control act on innovation in the manufacturing industry with the aim of enhancing and improving the product competitiveness of enterprises in this sector (Fig. 1).

Implementation of the functions leads to the following tasks:

- creating the necessary conditions to ensure financing of innovative activities in the manufacturing industry;

- providing manufacturing enterprises with highly qualified human resources;

- creating conditions for the modernization of the main production assets of manufacturing enterprises.

The operation of the control mechanism aimed at the implementation of functions related to consolidation of control subjects, their coordinated work, the intensification of the development of innovation in the manufacturing industry by creating conditions for the improvement and development of financial, personnel and productive capacity, given the degree of involvement of processing enterprises in the process of creating and implementing innovations.

The main goals of the proposed mechanism are : to

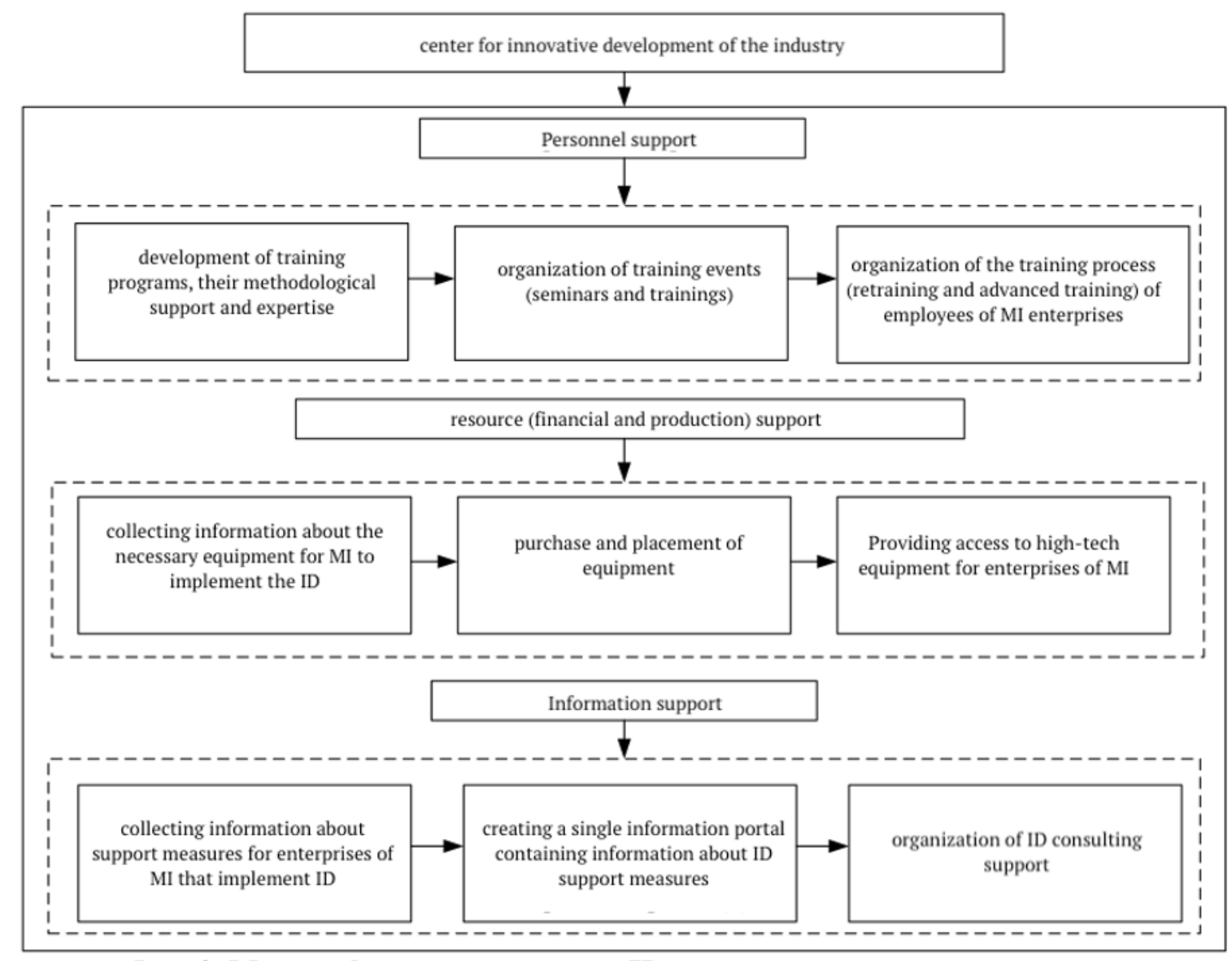

Fig. 2. Model of functioning of the center for innovative development of industry. 
activate innovative activities in the manufacturing industry, to increase the competitiveness of products produced in this sector.

As the main methods and tools, it is proposed to use direct economic methods (concessional lending; budget financing; subsidies; interest-free loans; price compensation; provision of state orders) and indirect (preferential taxation; restructuring of debts and payments of enterprises; property support for innovators; regulation of prices and tariffs; financial support for training and retraining of personnel; risk insurance, modernization loans) impacts, as well as organizational (creation of specialized structures that ensure interaction between participants in innovation activities), planned (development of strategies, programs and roadmaps for the development of innovation activities in the manufacturing industry), legal (improvement of the regulatory framework), administrative (development of the implementation process, expertise, licensing and monitoring of innovative projects) and information (formation of a system for providing consulting services; creating databases of innovative projects).

One of the priority tools aimed at enhancing innovation in the manufacturing industry is The center for innovative development of industry (Fig. 2). In contrast to the established structures of innovative infrastructure (center for applied qualifications, centre of excellence, centre of engineering, technology transfer center etc.) he allows, first, to provide an integrated (financial, personnel, production) support to manufacturing enterprises for the development, implementation and promotion of innovative products at all stages of the innovation cycle, and secondly, to ensure interaction of all participants of innovative activities within a single organizational structure, thirdly, take into account the degree of involvement of manufacturing enterprises in innovation.

The creation and development of the Center should be carried out at the expense of the Federal and regional budgets, as well as at the expense of enterprises. Resolution of the Government of the Russian Federation No. 316 of 15.04.2014" on approval of the state program of the Russian Federation "Economic development and innovative economy "(subprogram 5 "Promotion of innovation" and subprogram 7 "Personnel for the innovative economy") States as one of the priority tasks the need to create and develop mechanisms for comprehensive support of innovation activities at all stages. The State program "Economic development of the Vologda region for 2014-2020 "(Subprograms "Development of individual sectors of the regional economy and increasing competitiveness" and "Science and innovation in the Vologda region") also noted the creation of conditions for the modernization of production and innovative development in the region.

The effect of the activities of the Centre is calculated on the basis of such indicators as: the number created with the participation of the Center of innovations; the number implemented with the participation of the Centre of innovative developments in the manufacturing industry in the region; share of trained employees in the total number of those who need training and refresher training; the efficiency of use of borrowed and available resources; demand developed by the Centre for methodological support for learning process among the participants of innovative activity; the degree of depreciation of fixed assets of enterprises participating in the Center; the number of issued protection documents for inventions and utility models received by the participants of the Center.

Thus, in order to overcome the problems of developing innovative activities in the manufacturing industry associated with the lack of own financial resources, the unattractiveness of this sector for investors, the difficulty of obtaining borrowed funds, the high degree of depreciation of fixed assets, and the lack of highly qualified specialists, due to the lack of coordination between participants in innovation activities, the actions of Federal and regional authorities and management should be aimed at providing comprehensive support to enterprises in this sector with the predominant use of economic, organizational and information tools. At the same time, it is necessary to provide targeted support to manufacturing enterprises, taking into account the degree of their involvement in innovation and socio-economic factors that affect the process of creating and implementing innovations in this sector.

\section{References}

1. V. N. Borisov, O. V. Pochukaeva, Modernization of the manufacturing industry of the Russian Federation on the basis of sustainable development of domestic engineering, Problems of forecasting, 2, 55-63 (2011).

2. V. A. Ilyin, K. A. Gulin, T. V. Uskova, Intellectual resources as a factor of innovative development, Economic and social changes: facts, trends, forecast, 3, 14 (2010)

3. V. A. Ilyin, A. I. Povarova, Problems of efficiency of public administration. Trends in market transformations. The crisis of the budgetary system. The role of private capital. Strategy-2020: problems of implementation, 188 (Vologda: ISERT RAS, 2014).

4. N. I. Ivanov, V. V. Ivanov, Innovation policy: Russia and the World. 2002-2010, 451 (Moscow: Nauka, 2011).

5. E. A. Mazilov, Main indicators and factors of innovative development of the region's industry, Management and business administration, 1, 166178 (2013).

6. V.N. Makoveev, Innovative processes in domestic engineering, Management and business administration, 4, 96-106 (2013)

7. S. A. Ayvazyan, V. S. Mkhitaryan, Applied statistics. Fundamentals of econometrics. Vol. 1: probability Theory and applied statistics [Text]: textbook for universities: in 2 volumes, 656 (ISPR. M.: UNITY-DANA, 2001). 
8. I. I. Eliseeva, Statistics. Workshop [Text]: textbook. the allowance for high schools, 483 (2011).

9. S.V. Terebova, Industrial complex of the region: innovative aspect of development, Problems of Economics and management, 4, 54-59 (2011).

10. S. V. Terebova, A. M. Vyacheslavov, Innovative climate in the region: the composition and factors of development, Problems of territory development, 3, 40 (2011)

11. Federal state statistics service. Access mode: http://www.gks.ru

12. International Merchandise Trade Statistics [Electronic resource]. - Mode of access: http://comtrade.un.org/pb/CountryPagesNew.aspx?y $=2012$.

13. Eurostat [Electronic resource]. - Mode of access: http://epp.eurostat.ec.europa.eu.

14. A.G. Polyakova, S. A. Ramakrishna, V. V. Kolmakov, and D. V. Zavyalov, A Model of Fuel and Energy Sector Contribution to Economic Growth, International Journal of Energy Economics $\begin{array}{llll}\text { and Policy } 9 & \text { (5), 25-31 (2019). }\end{array}$ doi:10.32479/ijeep.7849. 